\title{
The Boundaryless Career Attitude and Organisational Commitment among Public Accountants in Penang, Malaysia
}

\author{
${ }^{*}$ Gim Chien Wei Gabriel ${ }^{1}$, Mat Desa Nasina ${ }^{2}$ \\ ${ }^{1}$ Wawasan Open University School of Business and Administration, Malaysia \\ ${ }^{2}$ Universiti Sains Malaysia School of Distance Education (Management), Malaysia \\ *nasinawou@gmail.com
}

\begin{abstract}
This paper aims to study the impact of boundaryless career attitude (organisational mobility preference and boundaryless mindset) on organisational commitment (affective commitment, continuance commitment, and normative commitment). Specifically, we predicted that employees who demonstrate a high boundaryless career attitude would be less committed to their employers. A sample of 132 public accountants was drawn from 15 accounting firms in Penang. A three-stage sampling was used in this study started with cluster sampling, followed by systematic sampling, and finally convenience sampling. Multiple regression analysis was used in the study and the results shown that organisational mobility preference was significantly negatively related to affective commitment, continuance commitment, and normative commitment. It also revealed that boundaryless mindset was significantly negatively related only to continuance commitment. Theoretically, the findings mainly supported the findings by Briscoe and Finkelstein (2009). Practically, the findings implied that practitioners of accounting firms should implement policies to cater to the needs of the boundaryless career actors by providing career relevant skills, training, meaningful jobs, and opportunities for secondment. In conclusion, this research revealed the growing importance of the boundaryless career attitude in affecting organisational commitment among public accountants in Penang, Malaysia.
\end{abstract}

Keywords: Boundaryless career, organisational commitment, public accountants, Malaysia

\section{Introduction}

This paper aims to study the impact of boundaryless career attitude (organisational mobility preference and boundaryless mindset) on organisational commitment (affective commitment, continuance commitment, and normative commitment).Organisational commitment has always been a topic of interest to academics studying on accountants in the public accounting environment (Ketchand \& Strawser, 2001). Accountants are professionals equipped with skills that are transferable from one organisation to another organisation. Everyone knows that every single organisation needs at least an accountant to manage his or her accounts. There is also a common cliché, which says accountancy is a recession proof profession. Organisational commitment is important because the lack of it could cause some adverse consequences. Meyer, Stanley, Herscovitch, and Topolnytsky (2002) showed that low levels of organisational commitment could lead to turnover intention, actual turnover, poor attendance, poor organisational citizenship behaviour, poor performance, and it affects employees' health and well-being. Parker and Kohlmeyer III (2005) found that low organisational commitment is a predictor of high turnover intention among public accountants. Due to the magnitude of organisational commitment, this paper looks into the organisational commitment among the public accountants in Penang, Malaysia. The term boundaryless career was coined by Arthur (1994) and popularised by Arthur and Rousseau (1996), who described it as occupational paths that are not bounded to a single organisation but expands across various organisations to develop competencies and human capital. Sullivan and Arthur (2006) have further conceptualised on the boundaryless career as one that comprises of two dimensions: physical mobility and psychological mobility. The traditional organisational career based on the traditional psychological contract where employees work for life in return for monetary reward and job security has been replaced by a new contract based on continuous learning and identity change (Hall, 1996). The traditional organisational career was the trend in the mid-80s and decades ago, where everyone was expected to follow the logic of vertical mobility within a firm but is no longer the norm today (Arthur \& Rousseau, 1996). The changing trend in careers and employment suggest that many employees no longer have strong commitment to their employers.

Organisational commitment hardly exists in accounting firms. Many accountants work in public accounting firms to gain technical expertise and valuable experience liaising with corporate clients, who 
might be their future employer (DeFillippi \& Arthur, 1994). As a result, these accountants will be very mobile in their careers, as they will leverage their experience working in accounting firms to gain entry into other corporate organisations, especially client firms (DeFillippi \& Arthur, 1994). Additionally, the accounting profession in Malaysia is suffering from brain drain as Malaysian accountants are flocking to places like China, Singapore, Hong Kong and UK (Tomlinson, Abdullah, Kolesnikov-Jessop, 2008). If the brain drain continues, this will lead to a chronic shortage of 16,000 qualified accountants in Malaysia by 2020 (Tomlinson et al., 2008). There is also a claim by a panellist at a forum organised by "Accountants Today" that was held in 2007 that the Malaysian accounting profession is suffering from brain drain and this issue needs to be addressed (Ravendran, 2008). Hence, a practical problem that plagues Malaysia deserved attention for a research to be done. This research hopes to fill in the research gap on the boundaryless career and organisational commitment literature and to add further understanding to the literature. Ever since the boundaryless career attitude scale was developed by Briscoe, Hall, \& DeMuth (2006), there is still minimal quantitative research being conducted on the boundaryless career attitude, furthermore, especially in Malaysia. This research therefore could also facilitate the development of new hypotheses for further research in this area. This research attempts to answer the research questions below:

- Is there a relationship between perceived organisational mobility preference and organisational commitment (affective commitment, continuance commitment, and normative commitment)?

- Is there a relationship between perceived boundaryless mindset and organisational commitment (affective commitment, continuance commitment, and normative commitment)?

\section{Literature Review}

Organisational Commitment: The term organisational commitment has been around since the 1960s. Academics have come a long way in defining organisational commitment in various ways. Becker (1960) was the first to conceptualise the term commitment, which lent towards fruitful academic discussion in the years to come. Meyer and Allen (1991) expanded the concept of organisational commitment as a psychological state that includes desire, need, and obligation to remain with an employer. As a result, they came up with a three-component model of organisational commitment, which had since led the way on new theoretical development on organisational commitment. According to them, the three components of organisational commitments are affective commitment, continuance commitment, and normative commitment. Meyer and Allen (1991) defined affective commitment as "employee's emotional attachment to, identification with, and involvement in the organisation". Employees will develop affective or emotional attachment to the employer when the employees share a common goal with the employer and are willing to assist the employer to achieve those goals (Ketchand \& Strawser, 2001). Meyer and Allen (1991) defined continuance commitment as "an awareness of the costs associated with leaving the organisation". Johnson, Chang, and Yang (2010) explained continuance commitment as the need to remain employed with the same employer due to the reluctance to forgo desirable personal outcomes or when there is a perceived lack of employment opportunities elsewhere. Meyer and Allen (1991) defined normative commitment as "a feeling of obligation to continue employment". Meyer \& Herscovitch (2001) claimed that employees develop normative commitment due to the obligation to reciprocate with loyalty and commitment after receiving benefits from the organisation or when there is internalisation of norms through socialisation.

Boundaryless Career Attitude: As emphasised by Arthur and Rousseau (1996), the boundaryless career is the opposite of the traditional organisational career. To understand the boundaryless career, one has to understand the traditional organisational career first. The traditional organisational career is characterised as a career that is bounded to a single large stable organisation with an orderly employment arrangements achieved through vertical coordination. This implies that the boundaryless career is "not tied to a single organisation, not represented by an orderly sequence, and marked by less vertical coordination and stability" (Briscoe \& Hall, 2006). One with a boundaryless career attitude would not remain within a single organisation or line of work over the course of their careers and would selfmanage their careers by seizing new opportunities to develop their human capital and employability (Cheramie et al., 2007). Employees who possess the boundaryless career attitude are said to be independent and mobile (Arthur \& Rousseau, 1994). Such employees do not rely on the traditional organisational career arrangements or plans laid out by their employers. Instead, they detach their identity from their employers and identify themselves to their vocation, careers, or profession (DeFillippi \& Arthur, 1994; Eby, Butts, \& Lockwood, 2003). Sullivan and Arthur (2006) conceptualised boundaryless career as a career that comprises two dimensions of mobility, which are physical mobility and 
psychological mobility. In another words, a boundaryless careerist would move between organisations (physical boundaries) and/or believe they have the capacity to move across boundaries (psychological boundaries) (Cheramie, Sturman, \& Walsh, 2007). Based on these two dimensions, Briscoe et al. (2006) conceptualised physical mobility as organisational mobility preference and psychological mobility as boundaryless mindset. Sullivan and Arthur (2006,) defined physical mobility as the "actual movement between jobs, firms, occupations and countries". Briscoe and Finkelstein (2009)interpreted physical mobility as organisational mobility preference meaning that a person has a strong desire to work for multiple organisations and will not just work in one organisation for a lifetime. Sullivan \& Arthur (2006) defined psychological mobility as "the capacity to move as seen through the mind of the career actor". Briscoe, Hall, \& DeMuth (2006) interpreted psychological mobility as boundaryless mindset and explained it as an attitude that initiates and pursues work-related relationships across organisational boundaries from a set location.

Boundaryless career and organisational commitment: The hypotheses that the boundaryless career attitude and organisational commitment is negatively correlated were first developed by Briscoe and Finkelstein (2009). Based on a logical argument, Briscoe and Finkelstein (2009) explored and hypothesised that career actors with boundaryless career attitude will be less committed to their employers because boundaryless career actors are more agentic, independent, and proactive and will not hesitate to leave their employers when their needs are not met. In this paper, we seek to understand the conclusion made by Briscoe and Finkelstein. This paper looks into the relationship of the boundaryless career attitude (organisational mobility preference and boundaryless mindset) on organisational commitment (affective commitment, continuance commitment, and normative commitment) among public accountants in Penang, Malaysia.

Figure 1: The Theoretical Framework of the Study

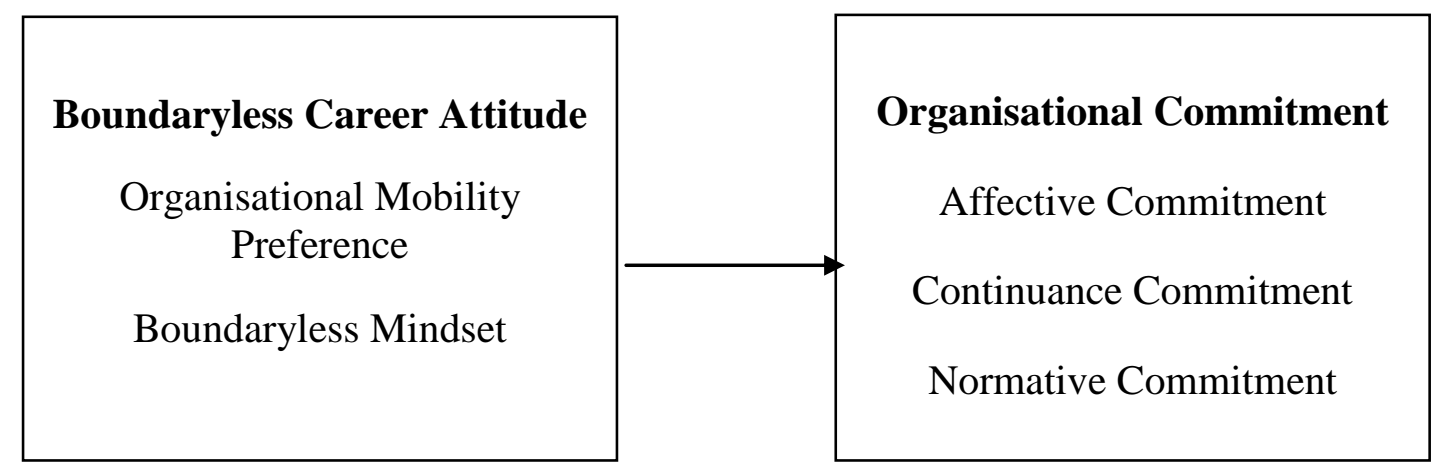

Development of Hypotheses

Organisational Mobility Preference and Organisational Commitment (Affective Commitment, Continuance Commitment, and Normative Commitment): Briscoe and Finkelstein (2009) claimed that those who like to switch jobs are less attached emotionally to their employers. Most importantly, they found support that organisational mobility preference was significantly negatively related to affective commitment. Hence,

H1. Perceived organisational mobility preference is negatively related to affective commitment.

Briscoe and Finkelstein (2009) added that those with strong preference for organisational mobility are more likely to leave the organisation due to their independent nature. Since they are independent, such individuals are not concerned about the job alternatives available. They added that those who like to switch jobs are less attached, for economic reasons, to their employers compared to those with lower preference for organisational mobility. Most importantly, they found support that organisational mobility preference was significantly negatively related to continuance commitment. Hence,

H2. Perceived organisational mobility preference is negatively related to continuance commitment.

Briscoe and Finkelstein (2009) claimed that normative commitment is virtually antithetical to the concept of boundaryless career. Hence, those who like to switch jobs have lower obligation to stay with their employers compared to those with lower preference for organisational mobility. Most importantly, they 
found support that organisational mobility preference was significantly negatively related to normative commitment. Hence,

H3. Perceived organisational mobility preference is negatively related to normative commitment.

Boundaryless Mindset and Organisational Commitment (Affective Commitment, Continuance Commitment, and Normative Commitment): According to the social exchange theory, when a boundaryless career actor who yearned for continuous learning and personal growth could not achieve their needs at their current workplace, they will lose their affective commitment and look for opportunities elsewhere (Fernandez \& Enache, 2008). Fernandez and Enache (2008) claimed that a person with boundaryless mindset will be inclined to pursue opportunities for continuous learning and personal growth will leave the company if the company could not provide such opportunities. Hence, according to the social exchange theory, Fernandez and Enache (2008) explained that such individuals will exhibit low affective commitment because there is no fit between the employee and the employer. For exploratory reasons, the hypothesis below is hence developed to be tested in the Malaysian environment.

H4. Perceived boundaryless mindset is negatively related to affective commitment.

Briscoe and Finkelstein (2009) hypothesised that boundaryless mindset is negatively correlated to continuance commitment. They argued that career actors with a strong boundaryless mindset will be more independent and will not be bothered about the lack of job alternatives available in the market. Hence, a career actor with a strong boundaryless mindset will possess a lower continuance commitment towards his employer.

However, Briscoe and Finkelstein (2009) did not find support on the hypothesis that boundaryless mindset is negatively related to continuance commitment. For exploratory reasons, the hypothesis below is developed to be tested in the Malaysian environment.

H5. Perceived boundaryless mindset is negatively related to continuance commitment.

Briscoe and Finkelstein (2009) hypothesised that boundaryless mindset is negatively correlated to normative commitment. They argued that normative commitment is virtually antithetical to the concept of boundaryless career. Hence, a career actor with a strong boundaryless mindset will possess a lower normative commitment towards his employer.

H6. Perceived boundaryless mindset is negatively related to normative commitment.

Based on Figure 1, in summary, six hypotheses are developed to test the relationship between boundaryless career attitude and organisational commitment.

H1. Organisational mobility preference is negatively related to affective commitment.

H2. Organisational mobility preference is negatively related to continuance commitment.

H3. Organisational mobility preference is negatively related to normative commitment.

H4. Boundaryless mindset is negatively related to affective commitment.

H5. Boundaryless mindset is negatively related to continuance commitment.

H6. Boundaryless mindset is negatively related to normative commitment.

\section{Methodology}

Questionnaires were distributed to public accountants working in mid-tier accounting firms in Penang using both probability sampling and non-probability sampling methods. Probability sampling was utilised at the first stage and the second stage while the non-probability sampling method was utilised at the third stage. At the first stage, cluster sampling was used to select the accounting firms located within the vicinity of Georgetown, Penang. From the Malaysian Institute of Accountants website, there are 146 midtier accounting firms located in the State of Penang. To select accounting firms that are located within the vicinity of Georgetown, the clusters are divided based on the postcodes. Based on the websites of Poskod.com and Dromoz.com, the postcodes located within the vicinity of Georgetown are 10000, 10050, $10100,10150,10200,10250,10300,10350,10400,10450,10460$, and 10470. At the second stage, systematic sampling was used to select the clusters. An interval of four was used starting from 10050 . 
Hence, the selected postcodes are 10050, 10250, and 10450. There are 30 mid-tier accounting firms located within these three postcodes. Out of these 30 firms which were contacted, only 15 firms agreed to participate in the survey. At the third stage, the questionnaires were distributed to all of the public accountants working in those 15 firms using a convenience sampling method. It is because these 15 firms declined to reveal the list of its employees' names. The researcher has no control on the distribution of the questionnaires within each accounting firms. A total of 223 questionnaires were distributed to those 15 accounting firms.

Boundaryless career attitude: Organisational mobility preference was assessed using the five-item measure developed by Briscoe et al. (2006). The scale was measured using a five-point Likert scale ranging from (1) "to a little or no extent" to (5) "to a great extent". The Cronbanch's alpha for this scale was .76 (Briscoe et al., 2006).Boundaryless mindset was assessed using the eight-item measure developed by Briscoe et al. (2006). The scale was measured using a five-point Likert scale ranging from (1) "to a little or no extent" to (5) "to a great extent". The Cronbach's alpha for this scale was .87 (Briscoe et al., 2006).

Organisational commitment: Affective commitment, continuance commitment and normative commitment were measured based on the scales developed by Meyer, Allen, and Smith (1993). Each of the components of commitment has 6-items respectively (Meyer et al., 1993). The Cronbach's alpha for the three scales are .82, .74, and .83 respectively (Meyer et al., 1993). All of these measures were measured using a five-point Likert scale ranging from (1) "strongly disagree" to (5) "strongly agree".

Demographic profiles: The demographic profiles of the respondents were assessed by age, gender, marital status, race, academic qualification, organisational tenure, current position, positional tenure, monthly salary, and department.

\section{Results and Analysis}

Out of the 223 questionnaires distributed, 145 were collected back, giving a response rate of $65 \%$. However, there were 13 questionnaires, which were deemed unusable because the questionnaires were filled in either incompletely or incorrectly. As a result, only 132 questionnaires can be used, giving a final response rate of 59\%.The demographic profiles of the 132 respondents are shown in Table 1 below.

Table 1: Demographic Characteristics of Respondents

\begin{tabular}{llll}
\hline $\begin{array}{l}\text { Demographic } \\
\text { variables }\end{array}$ & Categories & Frequency & Percentage (\%) \\
\hline Age & 30 and below & 115 & 87.1 \\
& $31-40$ years & 11 & 8.3 \\
Gender & $41-50$ years & 5 & 3.8 \\
& 51 and above & 1 & 0.8 \\
Marital Status & Female & 48 & 36.4 \\
& Single & 84 & 63.6 \\
& Married & 117 & 88.6 \\
Race & Separated/Divorced/Widowed & 15 & 11.4 \\
& Malay & 0 & 0 \\
& Chinese & 120 & 4.5 \\
Academic & Indian & 5 & 90.9 \\
Qualification & Others & 1 & 3.8 \\
& Certificate or Equivalent & 1 & 0.8 \\
& Diploma & 14 & 0.8 \\
& Advanced Diploma & 16 & 10.6 \\
& Bachelor's Degree & 67 & 12.1 \\
Organisational & 34 & 50.8 \\
Tenure & Professional Qualification & 0 & 25.8 \\
& Postgraduate & 65 & 0 \\
& Less than 1 year & 39 & 49.2 \\
& 1 - 3 years & 18 & 29.5 \\
& 4 - 6 years & 4 & 13.6 \\
\hline
\end{tabular}




\begin{tabular}{llll}
\hline \multirow{3}{*}{ Position } & More than 9 years & 6 & 4.5 \\
& Associate/Junior & 74 & 56.1 \\
& Semi-senior & 19 & 14.4 \\
& Senior & 24 & 18.2 \\
& Managerial & 13 & 9.8 \\
Positional & Director & 2 & 1.5 \\
Tenure & Less than 1 year & 75 & 56.8 \\
& 1-3 years & 43 & 32.6 \\
& 4-6 years & 9 & 6.8 \\
Monthly salary & 1 & 0.8 \\
& More than 9 years & 4 & 3.0 \\
& Relow RM2,001 & 75 & 56.8 \\
& RM3,001 - RM3,000 & 30 & 22.7 \\
& RM4,001 - RM5,000 & 18 & 13.6 \\
& More than RM5,000 & 4 & 3.0 \\
Department & Audit & 5 & 3.8 \\
& Tax & 98 & 74.2 \\
& Other Advisory Services & 18 & 13.6 \\
\hline
\end{tabular}

The data collected were analysed using the Statistical Package for Social Science (SPSS) software version 17.0. In Table 2 below, all of the variables have reliability coefficients of above the recommended level of .7 as suggested by Hair, Black, Babin, and Anderson (2010). The correlations between the variables are also shown in Table 2 below. A majority of them have correlations which are statistically significant at the 0.01 level. The correlation between affective commitment and continuance commitment is statistically significant at the 0.05 level. There was no correlation between boundaryless mindset and affective commitment.

Table 2: Descriptive of the Variables

\begin{tabular}{|c|c|c|c|c|c|c|}
\hline & Variables & 1 & 2 & 3 & 4 & 5 \\
\hline 1. & Organisational mobility preference & $(.82)$ & & & & \\
\hline 2. & Boundaryless mindset & $.20^{*}$ & $(.87)$ & & & \\
\hline 3. & Affective commitment & $-.30^{* *}$ & -.17 & $(.75)$ & & \\
\hline 4. & Continuance commitment & $-.52^{* *}$ & $-.29 * *$ & $.22^{*}$ & $(.79)$ & \\
\hline 5. & Normative commitment & $-.66^{* *}$ & -.06 & $.52 * *$ & $.41^{* *}$ & $(.89)$ \\
\hline
\end{tabular}

Reliability estimates (Cronbach's Coefficients Alpha) are shown in the diagonal.

** $p<.01$, correlation is significant at the .01 level

$* p<.05$, correlation is significant at the .05 level

Multiple regressions were performed on affective commitment, continuance commitment and normative commitment and the results are shown in three separate tables below. In Table 3 below with affective commitment as the dependent variable, the $R^{2}$ value revealed that $10 \%$ of the variance for affective commitment was explained by organisational mobility preference and boundaryless mindset. This multiple regression model was a significant model because the $F$ ratio was significant $(F=7.29, p<.01)$. It means that the combination of organisational mobility preference and boundaryless mindset was a good fit in predicting affective commitment. Looking at each predictors individually, organisational mobility preference $(\beta=-.28, p<.01)$ was a significant predictor for affective commitment. However, boundaryless mindset $(\beta=-.11, p>.10)$ was not found to be a significant predictor. Therefore, only organisational mobility preference was significantly negatively related to affective commitment. As a result, H1 was supported and H4 was not supported.

Table 3: Multiple Regression Results for Affective Commitment

\begin{tabular}{|c|c|}
\hline Independent Variables & Standardised Coefficients $(\beta)$ \\
\hline Organisational mobility preference & $-.28 * * *$ \\
\hline Boundaryless mindset & -.11 \\
\hline$R^{2}$ & .10 \\
\hline Adjusted $R^{2}$ & .09 \\
\hline$F$-change & 7.29 \\
\hline
\end{tabular}


In Table 4 below with continuance commitment as the dependent variable, the $R^{2}$ value revealed that $30 \%$ of the variance for continuance commitment was explained by organisational mobility preference and boundaryless mindset. It means that $70 \%$ of the variance for continuance commitment was explained by other unknown additional variables. This multiple regression model $(F=28.09, p<.01)$ was a significant model in predicting continuance commitment. Looking at each predictors individually, organisational mobility preference $(\beta=-.48, p<.01)$ was a significant predictor for continuance commitment. Additionally, boundaryless mindset $(\beta=-.20, p<.01)$ was also found to be a significant predictor for continuance commitment. Therefore, both organisational mobility preference and boundaryless mindset were significantly negatively related to continuance commitment. As a result, $\mathrm{H} 2$ and H5 were supported.

Table 4: Multiple Regression Results for Continuance Commitment

\begin{tabular}{ll}
\hline Independent Variables & Standardised Coefficients $(\boldsymbol{\beta})$ \\
\hline Organisational mobility preference & $-.48^{* * *}$ \\
Boundaryless mindset & $-.20^{* * *}$ \\
$R^{2}$ & .30 \\
Adjusted $R^{2}$ & .29 \\
$F$-change & 28.09 \\
\hline$* p .10,{ }^{* *} p<.05,{ }^{* * *} p<.01$ &
\end{tabular}

In Table 5 below where normative commitment is the dependent variable, the $R^{2}$ value revealed that $47 \%$ of the variance for normative commitment was explained by organisational mobility preference and boundaryless mindset. It means that $53 \%$ of the variance for normative commitment was explained by other unknown additional variables. This multiple regression model $(F=56.57, p<.01)$ was a significant model in predicting normative commitment. Looking at each predictors individually, organisational mobility preference $(\beta=-.70, p<.01)$ was a significant predictor for normative commitment. However, boundaryless mindset $(\beta=.07, \quad p>.10)$ was not found to be a significant predictor. Therefore, only organisational mobility preference was significantly negatively related to normative commitment. As a result, H3 was supported and H6 was not supported.

Table 5: Multiple Regression Results for Normative Commitment

\begin{tabular}{ll}
\hline Independent Variables & Standardised Coefficients $(\boldsymbol{\beta})$ \\
\hline Organisational mobility preference & $-.70^{* * *}$ \\
Boundaryless mindset & .07 \\
$R^{2}$ & .47 \\
Adjusted $R^{2}$ & .46 \\
$F$-change & 56.57 \\
\hline${ }^{*} p<.10,{ }^{* *} p<.05,{ }^{* * *} p<.01$ &
\end{tabular}

\section{Discussion and Conclusion}

The findings revealed that organisational mobility preference has a negative relationship with all components of organisational commitment, which are affective commitment, continuance commitment, and normative commitment. This is in congruence with the findings from Briscoe and Finkelstein (2009) in the United States. The result also supported the hypothesis that boundaryless mindset is negatively related to continuance commitment, contradicting with Briscoe and Finkelstein's finding. It is definitely refreshing to see this revelation to the contrary. The researchers therefore suggested that more research should be conducted to support or to annul the hypotheses that boundaryless mindset has a negative relationship with all of the three components of organisational commitment before calling for boundaryless mindset to be decoupled from organisational commitment. The results provided insights to practitioners in the public accounting profession in Malaysia. Since the study revealed that the organisational mobility preference has a significant negative relationship with all of the components of organisational commitment, employers must be able to cater to this growing appetite for mobility. One way to feed the public accountants preference for organisational mobility is by offering secondment opportunities. The employers of the public accounting firms must begin to explore the idea of seconding selected employees to other branches in another location, whether in Malaysia or in the overseas. The first limitation of the research is that the sample only comprised respondents from the public accounting profession within Penang. The result may not be generalised to the entire Malaysian workforce as a whole. Therefore, a similar research should be performed on respondents beyond the public accounting 
profession throughout Malaysia or on other samples of occupational settings to ensure the results could be generalised to the entire Malaysian workforce. Another limitation is that this current study only looked at the relationship between the boundaryless career attitude and organisational commitment. Further studies can be performed by adding a moderator. Briscoe and Finkelstein (2009) claimed that openness to experience or mastery-learning orientation would be a viable variable that moderates the relationship between the boundaryless career attitude and organisational commitment. Despite the limitations, the study contributes towards the literature on the boundaryless career attitude and organisational commitment. This study has demonstrated that a person with a strong preference for organisational mobility will exhibit a lower form of affective commitment, continuance commitment, and normative commitment. Furthermore, the study also showed that a person with a strong boundaryless mindset will exhibit a lower form of continuance commitment. With the coming of the boundaryless career era and the insatiable appetite for continuous learning and personal growth among employees today (Hall, 1996), it is even more important for employers to keep in check the commitment of their employees. Why? It is because committed employees are more likely to remain in the organisation than are uncommitted employees (Meyer \& Allen, 1997). Therefore, employers must also engage in continuous learning to learn how to feed the growing appetite for physical and psychological mobility among employees today.

\section{References}

Arthur, M. B. (1994). The boundaryless career: a new perspective for organizational inquiry. Journal of Organizational Behavior, 15, 295-306.

Arthur, M. B. \& Rousseau, D. (1996). The boundaryless career: A new employment principle for a new organizational era. New York: Oxford University Press.

Becker, T. E., Billings, R. S., Eveleth, D. M. \& Gilbert, N. L. (1996). Foci and bases of employee commitment: Implications for job performance. Academy of Management Journal, 39, 464-475.

Bellesi, B. E. (1999). The changing American workforce. Management Review, 3(9).

Briscoe, J. P. \& Finkelstein, L. M. (2009). The new career and organizational commitment: Do boundaryless and protean attitudes make a difference? Career Development International, 14, 242-260.

Briscoe, J. P. \& Hall, D. T. (2006). The interplay of boundaryless and protean careers: Combinations and implications. Journal of Vocational Behavior, 69, 4-18.

Briscoe, J. P., Hall, D. T. \& Demuth, R. L. F. (2006). Protean and boundaryless careers: An empirical exploration. Journal of Vocational Behavior, 69, 30-47.

Cheramie, R. A., Sturman, M. C. \& Walsh, K. (2007). Executive career management: Switching organizations and the boundaryless career. Journal of Vocational Behavior, 71, 359-374.

DeFillippi, R. J. \& Arthur, M. B. (1994). The boundaryless career: A competency based perspective. Journal of Vocational Behavior, 15, 307-324.

Fernandez, V. \& Enache, M. (2008). Exploring the relationship between protean and boundaryless career attitudes and affective commitment through the lens of a fuzzy set QCA methodology. Intangible Capital, 1(4), 31-66.

Eby, L. T., Butts, M. \& Lockwood, A. (2003). Predictors of success in the era of the boundaryless career. Journal of Organizational Behavior, 24, 689-708.

Gouldner, A. W. (1960). The norm of reciprocity: A preliminary statement. American Sociological Review, $25,161-178$.

Granrose, C. S. \& Baccili, P. A. (2006). Do psychological contracts include boundaryless or protean careers? Career Development International, 11, 163-182.

Hair, J. F., Black, W. C., Babin, B. J. \& Anderson, R. E. (2010). Multivariate Data Analysis: A Global Perspective. $7^{\text {th }}$ Ed. New Jersey: Pearson Prentice Hall.

Hall, D. T. (1996). Protean careers of the 21 $1^{\text {st }}$ Century. Academy of Management Executive, 10(4), 8-16.

Hipple, S. (1998). Contingent work: Results from the second survey. Monthly Labor Review, 3, 22-35.

Johnson, R. E., Chang, D. C. H. \& Yang, L. Q. (2010). Commitment and motivation at work: The relevance of employee identity and regulatory focus. The Academy of Management Review, 35, 226-245.

Ketchand, A. A. \& Strawser, J. R. (2001). Multiple dimensions of organizational commitment: Implications for future accounting research. Behavioral Research in Accounting, 13, 221-251.

Lawler, E. J. \& Thye, S. R. (1999). Bringing emotions into social exchange theory. Annual Review of Sociology, 25, 217-244.

Meyer, J. \& Allen, N. (1991). A three-component conceptualization of organizational commitment. Human Resource Management Review, 1, 61-89. 
Meyer, J. \& Allen, N. (1997). Commitment in the Workplace: Theory, Research, and Application, Thousand Oaks, California: Sage Publications.

Meyer, J. P., Allen, N. J. \& Smith, C. A. (1993). Commitment to organizations and occupations: Extension and test of a three-component conceptualization. Journal of Applied Psychology, 78, 538-551.

Meyer, J. P. \& Herscovitch, L. (2001). Commitment in the workplace: Toward a general model. Human Resource Management Review, 11, 299-326.

Meyer, J. P., Stanley, D. J., Herscovitch, L. \& Topolnytsky, L. (2002). Affective, continuance, and normative commitment to the organization: A meta-analysis of antecedents, correlates, and consequences. Journal of Vocational Behavior, 61, 20-52.

Parker, R. J. \& Kohlmeyer-III, J. M. (2005). Organizational justice and turnover in public accounting firms: A research note. Accounting, Organizations and Society, 30, 357-369.

Ravendran, A. (2008). Brain drain or global mobility. Accountants Today, 1, 20-24.

Robinson, S. L. \& Rousseau, D. M. (1994). Violating the psychological contract: Not the exception but the norm. Journal of Organizational Behavior, 15, 245-259.

Rousseau, D. M. (1989). Psychological and implied contracts in organizations. Employee Responsibilities and Rights Journal, 2, 121-139.

Rousseau, D. M. (1990). New hire perceptions of their own and their employer's obligations: A study of psychological contracts. Journal of Organizational Behavior, 11, 389-400.

Sullivan, S. E. \& Arthur, M. B. (2006). The evolution of the boundaryless career concept: Examining physical and psychological mobility. Journal of Vocational Behavior, 69, 19-29.

Tomlinson, P., Abdullah, N. A. \& Kolesnikov-Jessop, A. (2008). Dispatch (Asia version), Accounting and Business. Asia: ACCA.http://www.accaglobal.com/members/publications /accounting_business/archive/2008/February/3065956 (accessed February 17, 2011). 